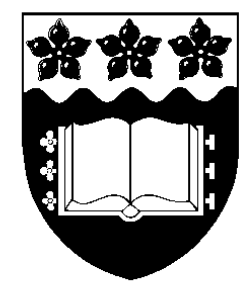

University of Wollongong

Economics Working Paper Series 2005

http://www.uow.edu.au/commerce/econ/wpapers.html

Export Performance and Destination Characteristics of Irish Manufacturing Industry

Frances Ruane

and

Julie Sutherland

WP 05-03

March 2005 


\title{
EXPORT PERFORMANCE AND DESTINATION CHARACTERISTICS OF IRISH MANUFACTURING INDUSTRY*
}

\author{
Frances Ruane \\ Department of Economics and Institute for International Integration Studies at Trinity College, Dublin \\ Julie Sutherland** \\ School of Economics, University of Wollongong, Australia and Institute for International Integration \\ Studies at Trinity College, Dublin
}

March 2005

\begin{abstract}
Recent research has sought to explore whether exporting enterprises have superior performance characteristics relative to non-exporters, and whether such superiority is associated with performance pre- and/or post- exporting. This paper extends existing research by examining the influence of export market destination on firm performance. It explores these issues using micro data on Irish manufacturing between 1991 and 1998, a time period during which Ireland experienced rapid export-driven growth. The study provides further evidence of the superior characteristics of exporters relative to nonexporters and supports the self-selection hypothesis that superior enterprises are more likely to export. We find export destination matters: the performance characteristics of enterprises that export globally differ from those that export locally.
\end{abstract}

KEY WORDS: Trade, Export Premium, Export Destination.

JEL Classification: F14

* The authors acknowledge financial support for the research on which this paper is based from Forfás, IDA Ireland, Enterprise Ireland and DEPFA BANK PLC (through the Institute for International Integration Studies (IIIS)), and comments on earlier drafts of this paper from Ali Uður and Anne Marie Gleeson (IIIS). The authors are grateful to the Central Statistics Office (CSO) of Ireland for the provision of data used in this study. To facilitate the research conducted the CSO gave the authors controlled access to anonymised micro data; this access is provided for in the Statistics Act, 1993 and was at all times within the CSO's premises under stringent conditions. We acknowledge assistance received from Patsy King and Tom McMahon. The paper has been screened by the CSO to ensure that no confidential data are revealed.

** Corresponding author: Julie Sutherland, School of Economics, University of Wollongong, NSW 2522,

Australia, Ph.61-2-42214017, Fax.61-2-42213725, julie_sutherland@uow.edu.au. 


\section{Introduction}

The macroeconomic significance of exporting for the promotion of economic growth at the country-level has been well documented (Ahmad and Kwan, 1991; and Greenaway and Sapsford, 1994). More recently, empirical micro-level investigation of the links between exporting and enterprise performance have emerged. ${ }^{1}$ The decision to participate actively in foreign markets is thought to expose enterprises both to greater competition and to options for increased output and efficiency. Consequently, the share of total sales accounted for by exports is seen to reflect the ability of an enterprise to cope with increased competition and to benefit from greater capacity utilisation, economies of scale, diversification of risk, and access to technology. Thus determining the characteristics responsible for export success at the enterprise level can be a means of establishing indicators for successful enterprise performance generally.

The increased availability of detailed microeconomic data sets has led to empirical research focusing on a number of aspects of the relationship between exporting and enterprise performance. Firstly, widespread evidence indicates that exporters in Germany (Bernard and Wagner, 1997), the US (Bernard and Jensen, 1999), the UK (Girma, Greenaway, and Kneller, 2002), Canada (Baldwin and Gu, 2003) and Sweden (Hansson and Lundin, 2004) are relatively larger in terms of employment and output, more capitalintensive, and more productive than their non-exporting counterparts. Several studies have also examined the issue of exporter performance in less developed countries, finding that exporters are more productive compared with non-exporters; these studies

\footnotetext{
${ }^{1}$ For a survey of empirical studies focusing on productivity and exporting, see Bartelsman and Doms (2000). Richardson and Rindal (1995) discuss the potential benefits of exporting.
} 
include Taiwan (Aw and Hwang, 1995), and Colombia, Mexico, and Morocco (Clerides, Lach, and Tybout, 1998). Regardless of the data examined and methodology used, these studies highlight the superior performance of exporters relative to non-exporters. However, the drivers of this superior performance are not clear and there are competing hypotheses regarding the result.

The first hypothesis is that enterprises self select to become exporters. Because of the additional costs associated with exporting, such as transportation, marketing, and distribution expenses, greater productivity is required of enterprises that become exporters. Consequently, the better than average performance of exporters may be simply due to producers self-selecting as exporters precisely because they are more efficient. Similarly, enterprises that are looking to enter a more competitive export market may have to reduce their costs prior to becoming exporters (Bernard and Wagner, 1997). Thus it could be expected that enterprises self-select themselves as exporters if the returns to entering exports markets are relatively high for them. ${ }^{2}$ If enterprises are successful before they begin exporting, then future exporters should exhibit relatively higher levels of productivity and superior characteristics relative to non-exporters in the years leading up to entering the foreign marketplace. This self-selection hypothesis is addressed empirically by looking at performance characteristics in the period prior to exporting using an export premium measure. Empirical results for US (Bernard and Jensen, 1999), German (Bernard and Wagner, 1997), and UK (Girma et al, 2002) manufacturing

\footnotetext{
${ }^{2}$ See Richardson and Rindal (1995) and Melitz (2003) for theoretical and practical explanations of why enterprises self-select to become exporters.
} 
exporters show significantly faster employment, shipment, and productivity growth relative to continuing non-exporters.

An alternative hypothesis is that the better performance of exporting enterprises may arise from the exporting process itself, through a type of "learning by exporting" experience. This occurs because the process of exporting improves productivity through economies of scale in production (as a result of serving a larger marketplace), information accessed in foreign markets, and the pressures on enterprise performance of the more intense competition involved in servicing the foreign marketplace. ${ }^{3}$ The learning by doing hypothesis is addressed empirically by looking at performance characteristics of exporters compared with non-exports in the period following their entry into export markets, again using an export premium measure. Empirical results regarding the impact of exporting on enterprise performance vary. Aw and Hwang (1995), Bernard and Wagner (1997), Bernard and Jensen (1995, 1999), and Clerides et al (1998) fail to find any evidence to support the learning-by-exporting hypothesis. On the other hand, results for the UK (Girma et al, 2002), Canada (Baldwin and Gu, 2003), and Sweden (Hansson and Lundin, 2004) find evidence to support the hypothesis that exporting actually boosts the productivity of the exporters examined.

One element of export behaviour not discussed widely in the literature relates to export destination, although recent theoretical work (Helpman, Melitz, and Yeaple, 2004; Eaton, Kortum and Kramarz, 2004) and empirical studies for French manufacturers (Eaton and

\footnotetext{
${ }^{3}$ Clerides et al (1998) provide a theoretical model of learning-by-doing. Bernard and Wagner (1997) provide a range of practical reasons for improvements in enterprise performance following exporting.
} 
Kortum, 2004) suggest that the relationship between enterprise performance and exporting does depend on the destination of exports. Exporting to a country with, for example, similar cultural and economic institutions may be akin to an enterprise supplying the domestic market if social and economic conditions are simply an extension of 'local' conditions. Conversely, exporting 'globally' to unfamiliar markets where social, economic, and legal structures are different from those normally faced may really be what exposes the enterprise to competitive pressures and greater learning opportunities. In effect, not all types of exporting are the same and the nature of the enterprise and export performance relationship may depend on the various conditions that different 'local' and 'global' export destinations present.

In this paper we use enterprise-level panel data of Irish manufacturing enterprises during the period 1991 to 1998 to investigate the performance of exporting enterprises relative to non-exporters by focusing our analysis on three questions: firstly, do exporting enterprises exhibit evidence of superior performance relative to non-exporters? Secondly, are exporters more efficient before they enter export markets; that is, do enterprises selfselect into selling onto international markets? Thirdly, do exporters learn to be relatively more efficient than non-exporters as a consequence of selling into export markets? ${ }^{4}$

The growth of Irish merchandise exports is considered a major factor contributing to Ireland's remarkable economic performance during the 1990s. However, most of the increase in manufactured exports in this period was generated by export-orientated

\footnotetext{
${ }^{4}$ The data are collected as part of the Census of Industrial Enterprises, conducted annually by the CSO, of enterprises that are engaged in industrial production in Ireland. An enterprise is defined as the smallest legal unit that is an organisational unit producing goods or services, which benefits from a certain degree of autonomy in decision making (for example, a company, a partnership, or a proprietorship).
} 
foreign-owned enterprises located in Ireland. The export performance of indigenous enterprises in the 1990s compared to previous time periods highlights the concern expressed about the international competitiveness of Irish-owned enterprises; between 1986 and 1991, the average annualised export growth rate of indigenous manufacturers was 12.3 per cent, but indigenous export growth fell to an average of 4.4 per cent per annum between 1991 and 1998 (Forfás, 2000, p.25). Thus the relatively slow export growth and declining share of indigenous exports in total Irish manufacturing exports during the 1990s highlights the importance of enterprise exporting and performance issues for Irish export competitiveness over the longer term.

Irish indigenous manufacturing has also been characterised by the changing destination pattern of exports during the 1990s. The historical dominance of the United Kingdom (UK) as an export destination continued to decline over the period, and other export destinations such as the European Union (EU) and the United States of America (US) became increasing important for Irish exporters. It is possible that the number of foreign marketplaces an Irish enterprise exports to, and that exporting beyond what could be considered the regional UK market, are indicators of the strength of the export activity of an enterprise. We explore the consequences of this changing pattern of export destination for the performance of Irish enterprises in Section 3 by distinguishing between local (UK) and global exporting.

The remainder of this paper develops as follows. Section 2 addresses the three questions listed above using Irish manufacturing data to estimate the export premium. Section 3 
examines whether there is a destination premium for those enterprises that export globally rather than locally. Section 4 concludes the paper.

\section{Measuring the Export Premium}

We begin this section by using data on Irish manufacturers to investigate whether or not exporters exhibit similar superior performance characteristics relative to non-exporters. Table 1 presents summary statistics for Irish manufacturing enterprises between 1991 and 1998 for each of seven enterprise characteristics used to define enterprise performance. ${ }^{5}$ The enterprise characteristics include both input and output measures. We capture the influence of the size of the enterprise by the value of the turnover of the enterprise (Turnover). Two measures of labour characteristics are included: the skill intensity of labour (Skilled labour) and average wages (Wages). The value of turnover produced by each employee (Productivity) is incorporated as a measure of productivity, and the gross value added (GVA) produced by each employee (Labour GVA) reflects the profitability of the enterprise. Finally, a measure of capital used by each employee (Capital intensity) is included to capture the capital intensity of the enterprise. All monetary values are measured in Irish pounds and converted to 1985 constant prices using appropriate deflators. ${ }^{6}$ The enterprise characteristics used here and throughout the paper are detailed in Appendix 1.

\footnotetext{
${ }^{5}$ These are based on 14,065 observations related to some 2,854 Irish-owned enterprises.

${ }^{6}$ All variables with the exception of capital intensity are deflated using the Industrial Producer Price Index (CSO, 1991b-98b), at the two and three-digit level. The capital intensity variable is deflated using the Wholesale Price Indices for Energy Products (CSO, 1991c-98c). The statistical summaries of enterprise data reported in this paper do not correspond to published enterprise figures (CSO, 1991-98a), which are not deflated.
} 
Table 1 shows that exporting enterprises are larger in terms of average employment, turnover, and gross value added, and have higher productivity and profitability as measured by turnover and gross value added per employee. Our objective is to determine whether such apparent differences between exporters and non-exporters are significant when we take account of relative enterprise size, industry and time. However, since it is possible that some of these differences may be due to industry composition, we need to account for differences in sectoral structure (exporters in different sectors to nonexporters) and focus on differences within sectors.

To measure the export premium, if any, for each of the seven enterprise characteristics, we adopt the methodology introduced by Bernard and Jensen (1995) and Bernard and Wagner (1997). The model searches for an export premium, as a measure of the superiority of exporters relative to non-exporters, in terms of enterprise characteristics and performance. Using enterprise-level data, the export premia are estimated using a regression of the form (1) as

$$
\ln V_{i t}=\alpha+\beta_{1} \text { Export }_{i t}+\beta_{2} \text { Size }_{i t}+\beta_{3} \text { Industry }_{i t}+\beta_{4} \text { Year }_{t}+\varepsilon_{i t}
$$

where $V_{i t}$ is the performance characteristic examined to determine if there is a premium between exporting and non-exporting enterprises $(i)$, on an annual basis $(t)$. The premium is captured by using a dummy variable, Export ${ }_{i t}$, to reflect the current export status of the enterprise ( 0 for non-exporter, 1 for exporter). The export premium coefficient $\left(\beta_{1}\right)$ thus captures the average percentage difference between exporters and non-exporters in the same industry. The dummy variable Size $_{i t}$ takes the value of one 
when the number of employees is above the median employment level across all DOEs in each given year, zero otherwise. ${ }^{7}$ Industry $_{i t}$ is a vector of four-digit sectoral dummy variables $^{8}$ and Year $_{t}$ is a vector of year dummies included to control for general business cycle effects. ${ }^{9}$ Although the data are based on a full census they do not form a balanced panel as some enterprises commenced production after 1991 whilst others ceased production during the period considered. Consequently, we use random effects panel data regression techniques to estimate (1) separately for each of the seven enterprise characteristics and confirm our choice with a Hausman test for each estimation. Table 2 reports the results.

Despite obvious differences in country size, our results for Irish manufacturing reflect those of existing studies for manufacturing sectors in the larger US, German, and UK manufacturing sectors. We find that exporting is positively and significantly related to all our measures of enterprise performance, after controlling for size, sector, and time and enterprise specific effects. On average, Irish-owned exporting enterprises are larger in terms of turnover, pay higher average wages, and employ a higher share of skilled employees relative to non-exporters. They are also more productive, in terms of both

\footnotetext{
${ }^{7}$ Median employment fluctuated between 30 and 32 over the period.

${ }^{8}$ The data are categorised at a sectoral level using the standard 4-digit NACE Rev. 1 classification (CSO, 1991a-98a).

${ }^{9}$ We assume that the error term in equation (1) is composed of two components, namely $\varepsilon_{i t}=\mu_{i}+v_{i t}$, with $\mu_{i}$ capturing an enterprise-specific permanent and unobservable effect, and $v_{i t}$ the remaining periodspecific error term, assumed to be independent across enterprises and over time.
} 
turnover and GVA per employee, and the production techniques used by exporters are more capital intensive than those of non-exporters. ${ }^{10}$

In large developed economies with significant domestic markets it is possible to achieve economies of scale and scope without exporting. However, in economies with small domestic markets, such as Ireland, enterprises that wish to achieve scale efficiency may need to export at a relatively early stage of the production life cycle if they are to reach critical mass. This raises the issue of whether enterprises self-select to become exporters. The costs associated with selling products in foreign markets can act as a barrier to entry to exporting for less successful and marginal enterprises. As a result, more productive and efficient enterprises are expected to be able to absorb the additional expenses incurred when entering a foreign market. Thus the intention to become an exporter stimulates improved performance by the enterprise and we would expect to find significant differences between exporters and non-exporters in our performance indicators prior to the enterprise becoming an exporter.

To examine the self-selection hypothesis we select continuously operating enterprises who did not export in years 1992 to 1996, but who may or may not be an exporter in 1997. ${ }^{11}$ Of the 289 non-exporting enterprises operating between 1992 and 1996, only 17 became exporters in 1997. Following Bernard and Jensen (1999) we regress the levels of

\footnotetext{
${ }^{10}$ Our results for labour productivity contrast with those of Girma et al (2004) who find that there is no significant difference in labour productivity between Irish exporters and non-exporters.

${ }^{11}$ By selecting continuously operating enterprises that did not export in 1992 through 1996, we ensure that enterprises did not switch export status between years 1991-1992 and 1997-1998.
} 
our performance measures in the initial sample year (1992) on the export status of the enterprise in the final sample year (1997). Hence the model estimated is

$$
V_{i 92}=\alpha+\beta_{1} \text { Export }_{i 97}+\beta_{2} \text { Size }_{i 92}+\beta_{3} \text { Industry }_{i 92}+\varepsilon_{92}
$$

where $V_{i 92}$ is the enterprise characteristic in 1992, measured in logarithms. Export ${ }_{i 97}$ is the dummy variable for export status in 1997 . The export premium coefficient, $\beta_{1}$, shows the average difference between enterprises that became exporters in 1997 relative to those enterprises that remained non-exporters in 1997, within the same sector. The dummy variable for size $\left(\right.$ Size $\left._{i 92}\right)$ is adjusted to the relevant median employment. ${ }^{12}$

Table 3 reports the results of differences in initial performance levels between future exporters and continuing non-exporters. Future exporters are found to be larger than nonexporters in terms of turnover. Most notable is the productivity premium that future exporters appear to have over continued non-exporters, with both turnover and GVA per employee being significantly greater for future exporters. Average wage levels for employees of future exporters also appear to be relatively higher than those at continuously non-exporting enterprises. ${ }^{13}$ Our results suggest that in the years prior to entering the export market, future exporting enterprises are larger and more productive than those that remain non-exporters. These results are consistent with those obtained for both US and UK manufacturers, where exporters have a significant productivity premium to non-exporters at each point in time prior to entering the international marketplace.

\footnotetext{
12 The relevant median is circa 26 employees.

${ }^{13}$ To test the robustness of our results we evaluated the performance of future exporters relative to future non-exporters by estimating (2) using different initial years (1993, 1994, 1995). Our results support the findings presented for 1992 as the initial sample year.
} 
A third issue surrounding the premium associated with exporting examines the question of whether or not exporting itself enhances the performance characteristics of enterprises. Such a premium would be expected if exporters achieve improved productivity via economies of scale in production as a result of serving a larger marketplace. Also, greater competition in international markets relative to the domestic market could force enterprises to become more efficient in their methods of production in order to remain exporters. If this occurs we would expect the post-entry performance of exporters to be superior to continuing non-exporters and they should exhibit relatively stronger growth after they begin exporting.

To examine the relationship between the exporting and subsequent enterprise performance we use a sample comprising 1,002 continuously operating enterprises between 1992 and $1997 .{ }^{14}$ Of the 1,002 enterprises, 45 per cent were continuous exporters over the period, 21 per cent were continuous non-exporters, and the remaining enterprises changed or switched export status at some stage between 1992 and $1997 .^{15}$

To understand the transformations that may occur when enterprises enter export markets and to identify more precisely any potential benefits from exporting we follow Bernard

\footnotetext{
${ }^{14}$ In a similar manner to the previous analysis, we test a sample of continuously operating enterprises between 1991 and 1998 and remove those enterprises that switched export status in 1991 and/or 1998 in order to ensure that the sample of 1992 to 1997 enterprises are continuous exporters or non-exporters between 1991 and 1998.

${ }^{15}$ That is, if the enterprise was an exporter in year $(t)$ and became a non-exporter in year $(t+1)$, or was a non-exporter in year $(t)$ and became an exporter in year $(t+1)$, then it is defined as an enterprise that switched export status.
} 
and Jensen (1999) and estimate the following growth rate equation for each of our seven performance characteristics,

$$
\begin{aligned}
& \Delta V_{i 92}=\frac{\ln V_{i 97}-\ln V_{i 92}}{5} \\
& =\alpha+\beta_{1} \text { ContExp }_{i}+\beta_{2} \text { Switch }_{i}+\beta_{3} Z_{i 92}+\beta_{4} \text { Industry }_{i 92}+\varepsilon_{i}
\end{aligned}
$$

where $\operatorname{ContExp}_{i}$ is a dummy variable equal to one if the enterprise exported continuously during the 1992 to 1997 period, zero otherwise. Switch ${ }_{i}$ is a dummy variable equal to one if the enterprise switched export status at some point during the period, whether the enterprise entered the export market or exited from it. ${ }^{16}$ The coefficients $\beta_{1}$ and $\beta_{2}$ thus capture the increase in growth rates for exporting and switching enterprises respectively, relative to those that remained non-exporters throughout the 1992 to 1997 period. $Z^{\prime}{ }_{i 92}$ is a vector of enterprise characteristics in 1992 that includes a dummy variable for the enterprise $\operatorname{size}^{17}$, the average wage, and capital intensity. Equation (3) is estimated separately for each of the seven enterprise characteristics using cross-sectional regression estimation. Table 4 reports the results on the differences in growth rates between exporters, switchers, and non-exporters.

Relative to continuous non-exporters, continuous exporters showed no difference in the growth rates of the seven characteristics considered. The same result extends to enterprises that switched export status between 1992 and 1997: switching enterprises showed no significant differences in their performance characteristic growth rates relative

\footnotetext{
${ }^{16}$ The dummy variable takes the value of one if the enterprise either entered or exited the export market. It does not distinguish between the two, but simply defines those enterprises that 'switched' export status.

${ }^{17}$ The dummy variable for size is equal to one if enterprise employment was greater than 34 in 1992.
} 
to continuous non-exporters. ${ }^{18}$ The lack of evidence found in Irish manufacturing to support the hypothesis that exporting enhances enterprise performance is consistent with the results obtained for manufacturers in Germany and the US. The lack of evidence for export-enhancing growth would suggest that Irish exporters do not necessarily perform better once they become exporters relative to those who serve the domestic market exclusively.

\section{Measuring the Export Destination and Intensity Premium}

A feature of this paper is the introduction of export destination into the export premium literature, reflecting the possibility that the destination of exports may be correlated with the characteristics of enterprises and their propensity to export. As UNCTAD (2002) notes, successful exporting involves more than just increasing international market shares, because greater export diversification, reflected by changing export destinations, could be an indication of the improved export propensity of enterprises. Moreover, exporting more intensively can reflect improved competitive performance of existing exporters. Thus by incorporating export destination patterns and intensity into the analysis of export premia, account is taken of important components of the export behaviour of enterprises.

The number and type of export destination markets to which enterprises ship their output can be viewed as proxies for the strength of export activity; enterprises that export to

\footnotetext{
${ }^{18}$ As a measure of robustness, equation (3) was also regressed with the inclusion of the continuous exporter dummy variable relative to continued non-exporters, and the switching dummy variable relative to continuous non-exporters. In both cases the same insignificant results as presented in Table 4 were obtained.
} 
countries with similar economic, political, and cultural conditions may not have to be as competitive as those that export to less traditional markets, where distribution networks are less well established and institutional barriers to exporting must be overcome. Thus a reduced dependence on 'local' export markets and a greater propensity to export to more 'global' marketplaces could be interpreted as an improvement in the export performance of enterprises.

This issue is of considerable interest to Ireland as its export promotion strategy has attempted to reduce dependency on the UK market by expanding exports beyond this traditional and primary destination. Table 5 details the shares of output exported by Irish manufacturers to UK and Non-UK destinations between 1991 and 1998, during which there was relatively little change in the destination pattern of exports with approximately 43 per cent and 57 per cent of Irish manufactured exports shipped to the UK and Non-UK respectively.

The relatively lower transaction and transportation costs associated with exporting to the UK, combined with the historical economic, institutional, and social ties, and the trade agreements that have evolved over previous decades, have given Irish enterprises relatively greater trade access to UK markets. Thus the UK could be considered as a 'local' market, with Non-UK destinations being part of the 'global' market. As a consequence, enterprises that export to non-UK destinations may be expected to have superior performance characteristics relative to enterprises that export to the UK, as NonUK exporters need to be more competitive and efficient in order to break into these non- 
traditional markets. Thus we search for differences in the performance of enterprises that export to the UK relative to Non-UK destinations.

Along with export diversification, another feature of export success is greater export intensity, that is, exporting a larger proportion of enterprise turnover. In order to ensure that the average effects determined in Section 2 are representative we investigate whether or not there is significant variation in the premium of exporting that is related to export intensity. Despite government policies encouraging Irish enterprises to export, Table 5 notes that both the proportion of enterprises exporting $(60$ percent $)$ and their corresponding export intensity (36 per cent) remained constant between 1991 and $1998 .{ }^{19}$ The stability of export intensity may reflect a lack of productivity improvement and the associated performance characteristics required for enterprises to overcome the costs associated with becoming more embedded in export marketplaces. Enterprises that export more intensively could thus be expected to exhibit superior performance characteristics relative to less intensive exporters.

We incorporate export intensity and export destination into our export premia calculations using (4) and data comprising Irish exporting enterprises only. ${ }^{20} \mathrm{We}$ postulate that enterprises that export more intensively and to Non-UK destinations will exhibit superior performance characteristics relative to enterprises that export less intensively and primarily to the UK.

$$
V_{i t}=\alpha+\beta_{1} \text { NonUKInt }_{i t}+\beta_{2} \text { ExpInt }_{i t}+\beta_{3} \text { Size }_{i t}+\beta_{4} \text { Industry }_{i t}+\beta_{5} \text { Year }_{t}+\varepsilon_{i t}
$$

\footnotetext{
${ }^{19}$ Although the volume of exports by enterprises did rise between 1991 and 1998 .

${ }^{20}$ The data set comprises a maximum of 8,363 observations related to some 1,980 enterprises.
} 
NonUKInt $_{i t}$, the proportion of exports shipped to Non-UK destinations, distinguishes enterprises on the basis of their non-dependence on the UK market. If Non-UK exporters have superior performance characteristics relative to UK exporters, then the expected sign of $\beta_{1}$ is positive. ExpInt ${ }_{i t}$, the share of exports in enterprise turnover, captures the expected premium accruing to enterprises that export more intensively than others. We control for enterprise size, sector and time effects as before. Table 6 presents the regression results.

Enterprises that export more intensively are, on average, larger in terms of turnover and also tend to pay slightly higher wages than less intensive exporters. However, there is little if any significant difference in productivity or capital intensity amongst exporters of differing intensities and the coefficient of skill is actually significant and negative, implying that enterprises exporting more intensively use a smaller share of skilled labour. The coefficient of the export destination variable confirms our hypothesis about enterprise performance and export destination, suggesting that Non-UK exporters are larger than UK-exporters in terms of turnover and pay increasingly higher wages. NonUK exporters also tend to employ a higher proportion of skilled labour than UKexporters and are more productive as measured by turnover per employee. These results thus provide evidence of differences in the performance characteristics of enterprises based upon export destination, suggesting that UK-exporters face lesser barriers to trade and productivity requirements than Non-UK exporters. 


\section{Summary and Conclusion}

This paper has attempted to measure empirically the relationship between various aspects of enterprise performance and exporting, and extended the literature in this area by incorporating export destination patterns as a factor in this relationship.

Following the methodological approach established by Bernard and Wagner (1997) and Bernard and Jensen (1999), we find that Irish manufacturing exporters clearly exhibit superior performance characteristics relative to non-exporters. We find, moreover, that relatively intensive exporters have some superior characteristics compared to those that export proportionately less of their output, but these results are less robust. The performance of exporters before and after exporting is also explored; we find that 'superior' enterprises become exporters, but there is no evidence that enterprises improve their performance once they are in the export market. Furthermore, the significance of enterprise size throughout our analysis indicates that relatively larger enterprises are more likely to be exporters.

A feature of our analysis has been the introduction of the role of destination in the relationship between enterprise performance and exporting. Given the unique trade relationship between Ireland and the UK, we hypothesised that the UK is effectively a 'local' market for Irish manufacturers, so that exporters to the UK display dissimilar enterprise characteristics to Non-UK exporters. Our results confirm this, showing that Non-UK exporters are larger and more productive than UK-exporters, giving support to 
our hypothesis that exporters to Non-UK destinations have superior performance characteristics compared to enterprises that export primarily to the UK.

The empirical questions addressed in this paper are important for understanding the role of trade at the enterprise level, as well as for formulating policies that seek to promote growth through exporting. The analysis presented highlights the need for enterprises to be relatively more productive in order to enter the export market compared to continuing non-exporters and, because our results suggest that those enterprises that seek to export globally are superior to those that export locally, the destination pattern and not merely the scale of exporting may influence the success of exporters. 
Table 1:Characteristics of Irish Manufacturing Enterprises

\begin{tabular}{|c|c|c|}
\hline 1991 - 1998 Average & Mean & Standard deviation \\
\hline \multicolumn{3}{|l|}{ 1. Domestic enterprises } \\
\hline \multicolumn{3}{|l|}{14,065 Observations } \\
\hline \multicolumn{3}{|l|}{ 2,854 Enterprises } \\
\hline Employment & 59 & 114 \\
\hline Skilled labour share & $23.9 \%$ & $16.2 \%$ \\
\hline Average wages & $£ 10,073$ & $£ 4,635$ \\
\hline Turnover & $£ 5,317,577$ & $£ 16,400,000$ \\
\hline Turnover per employee & $£ 69,719$ & $£ 97,115$ \\
\hline GVA per employee & $£ 19,176$ & $£ 21,409$ \\
\hline Capital intensity proxy & $£ 1,326$ & $£ 2,343$ \\
\hline \multicolumn{3}{|c|}{ 2. Non-exporting enterprises } \\
\hline \multicolumn{3}{|l|}{ 5,593 Observations } \\
\hline Employees & 38 & 53 \\
\hline Average wage & $£ 9,545$ & $£ 4,575$ \\
\hline Skilled labour share & $22.78 \%$ & $15.03 \%$ \\
\hline Turnover & $£ 3,051,053$ & $£ 8,234,967$ \\
\hline Turnover per employee & $£ 61,982$ & $£ 91,687$ \\
\hline GVA per employee & $£ 18,303$ & $£ 19,306$ \\
\hline Capital intensity proxy & $£ 1,235$ & $£ 1,932$ \\
\hline \multicolumn{3}{|l|}{ 3. Exporting enterprises } \\
\hline \multicolumn{3}{|l|}{8,472 Observations } \\
\hline Employees & 73 & 139 \\
\hline Average wage & $£ 10,422$ & $£ 4,641$ \\
\hline Skilled labour share & $24.56 \%$ & $16.92 \%$ \\
\hline Turnover & $£ 6,813,879$ & $£ 20,000,000$ \\
\hline Turnover per employee & $£ 74,827$ & $£ 100,216$ \\
\hline GVA per employee & $£ 19,751$ & $£ 22,673$ \\
\hline Capital intensity proxy & $£ 1,386$ & $£ 2,577$ \\
\hline
\end{tabular}

Source: Own estimates derived from the Census of Industrial Enterprises.

All monetary values in 1985 constant $£$ IR. 
Table 2:Superior Performance Characteristics of Exporters v. Non-exporters

\begin{tabular}{lcccccc}
\hline \hline Export premium & $\begin{array}{c}\text { Skilled } \\
\text { labour } \\
\text { share }\end{array}$ & $\begin{array}{c}\text { Average } \\
\text { wages }\end{array}$ & Turnover & Productivity & $\begin{array}{c}\text { Labour } \\
\text { GVA }\end{array}$ & $\begin{array}{c}\text { Capital } \\
\text { intensity }\end{array}$ \\
\hline \hline & & & & & & \\
Export premium & $.062 * * *$ & $.057 * * *$ & $.163^{* * *}$ & $.105^{* * *}$ & $.077 * * *$ & $.121^{* * * *}$ \\
& $(.009)$ & $(.006)$ & $(.009)$ & $(.008)$ & $(.014)$ & $(.014)$ \\
Size & $-.181^{* * *}$ & $-.014 * *$ & $.447 * * *$ & $-.082^{* * *}$ & .004 & $-.136^{* * *}$ \\
& $(.010)$ & $(.007)$ & $(.011)$ & $(.009)$ & $(.015)$ & $(.014)$ \\
Observations & 13,902 & 14,063 & 14,065 & 14,065 & 13,785 & 14,017 \\
Enterprises & 2,828 & 2,854 & 2,854 & 2,854 & 2,837 & 2,849 \\
$\mathrm{R}^{2}$ overall & 0.323 & 0.367 & 0.565 & 0.538 & 0.293 & 0.480 \\
$\chi^{2}$ & $1,974.56$ & $3,372.67$ & $8,103.94$ & $4,405.53$ & $1,707.54$ & $3,222.99$ \\
Prob.> $\chi^{2}$ & 0.0000 & 0.000 & 0.000 & 0.000 & 0.000 & 0.000 \\
\hline \hline
\end{tabular}

Note: $\quad$ Summary regression results derived from (1).

Standard errors in parentheses.

Statistically significant at $* * * 1$ per cent, $* * 5$ per cent.

Table 3: Performance Premium of Future Exporters

\begin{tabular}{lcccccc}
\hline \hline $\begin{array}{l}\text { Export } \\
\text { premium for } \\
\text { future } \\
\text { exporters }\end{array}$ & $\begin{array}{c}\text { Skilled } \\
\text { labour } \\
\text { share }\end{array}$ & $\begin{array}{c}\text { Average } \\
\text { wages }\end{array}$ & Turnover & Productivity & Labour & Capital \\
& & & & & & \\
\end{tabular}

1992-1997

289 Enterprises

$\begin{array}{lcccccc}\text { Export } & .230 & .233 * * * & .725 * * * & .461 * * * & .449 * * * & -.323 \\ & (.141) & (.077) & (.224) & (.161) & (.136) & (.293) \\ \text { Size } & -.011 & .235 * * * & 1.111^{* * *} & .248 * * * & .224 * * & .183 \\ & (.082) & (.054) & (.128) & (.084) & (.097) & (.129) \\ & & & & & & \\ \text { Observations } & 286 & 289 & 289 & 289 & 286 & 288 \\ \mathrm{R}^{2} & 0.435 & 0.563 & 0.750 & 0.739 & 0.468 & 0.602\end{array}$

Note: $\quad$ Summary regression results derived from (2).

Standard errors in parentheses.

Statistically significant at $* * * 1$ per cent, $* 10$ per cent. 
Table 4: Enterprise Characteristics Post-Exporting

\begin{tabular}{lcccccc}
\hline \hline $\begin{array}{l}\text { Growth } \\
\text { premium } \\
\text { post- } \\
\text { exporting }\end{array}$ & $\begin{array}{c}\text { Skilled } \\
\text { labour } \\
\text { share }\end{array}$ & $\begin{array}{c}\text { Average } \\
\text { wages }\end{array}$ & Turnover & Productivity & $\begin{array}{c}\text { Labour } \\
\text { GVA }\end{array}$ & $\begin{array}{c}\text { Capital } \\
\text { intensity }\end{array}$ \\
\hline \hline & & & & & & \\
$\mathbf{1 9 9 2 - 1 9 9 7}$ & & & & & & \\
$\mathbf{1 , 0 0 2}$ Enterprises & & & & & & \\
& & & & & & \\
ContExp & -.006 & .008 & .007 & .003 & .013 & .006 \\
& $(.009)$ & $(.005)$ & $(.007)$ & $(.006)$ & $(.012)$ & $(.012)$ \\
Switch & .010 & .002 & .010 & .006 & .001 & .011 \\
& $(.008)$ & $(.004)$ & $(.006)$ & $(.005)$ & $(.009)$ & $.011)$ \\
Size & $.017 * * *$ & $.007 *$ & -.004 & $.014 * *$ & .006 & .010 \\
& $(.006)$ & $(.004)$ & $(.006)$ & $(.004)$ & $(.008)$ & $(.009)$ \\
Observations & 993 & 1,002 & 1,001 & 1,001 & 973 & 998 \\
$\mathrm{R}^{2}$ & 0.156 & 0.289 & 0.266 & 0.257 & 0.206 & 0.183 \\
& & & & & & \\
\hline \hline
\end{tabular}

Note: $\quad$ Summary regression results derived from (3).

Standard errors in parentheses.

Statistically significant at $* * * 1$ per cent, $* * 5$ per cent, and $* 10$ per cent.

Table 5: Export Features of Domestic-Owned Enterprises in Ireland, 1991- 1998

\begin{tabular}{|c|c|c|c|}
\hline Enterprise feature & 1991 & 1998 & \\
\hline Number of enterprises & 1,620 & 1,945 & \\
\hline Proportion of exporting enterprises $(\%)$ & 61.2 & 60.1 & \\
\hline Export intensity of enterprises ${ }^{*}(\%)$ & 35.0 & 35.7 & \\
\hline Export destination of enterprises & \multicolumn{2}{|c|}{$\begin{array}{c}\text { Percent of total exports by } \\
\text { destination }\end{array}$} & $\begin{array}{c}1991-1998 \\
\text { Volume Change } \\
(\%)\end{array}$ \\
\hline UK & 43.1 & 42.2 & 23.8 \\
\hline Non-UK & 56.9 & 57.8 & 28.5 \\
\hline
\end{tabular}

Source: Own estimates derived from the Census of Industrial Enterprises.

* Export intensity is defined as turnover exported as a proportion of total turnover. 
Table 6: Export and Destination Intensity Premia

\begin{tabular}{lcccccc}
\hline \hline Exporters & $\begin{array}{c}\text { Skilled } \\
\text { labour } \\
\text { share }\end{array}$ & $\begin{array}{c}\text { Average } \\
\text { wages }\end{array}$ & Turnover & Productivity & $\begin{array}{c}\text { Labour } \\
\text { GVA }\end{array}$ & $\begin{array}{c}\text { Capital } \\
\text { intensity } \\
\text { proxy }\end{array}$ \\
\hline \hline Destination & $.033^{*}$ & $.033^{* * *}$ & $.084^{* * *}$ & $.046^{* * *}$ & -.009 & -.029 \\
intensity & $(.018)$ & $(.013)$ & $(.020)$ & $(.017)$ & $(.028)$ & $(.026)$ \\
Export & $-.105^{* * *}$ & $.043^{* * *}$ & $.185^{* * *}$ & .036 & .052 & .010 \\
intensity & $(.024)$ & $(.016)$ & $(.027)$ & $(.023)$ & $(.035)$ & $. .034)$ \\
Size & $-.173^{* * *}$ & -.008 & $.505^{* * *}$ & $-.068^{* * *}$ & .015 & $-.125^{* * *}$ \\
& $(.013)$ & $(.009)$ & $(.015)$ & $(.012)$ & $(.019)$ & $(.019)$ \\
Observations & 8,301 & 8,363 & 8,363 & 8,363 & 8,172 & 8,344 \\
Enterprises & 1,968 & 1,980 & 1,980 & 1,980 & 1,964 & 1,977 \\
$\mathrm{R}^{2}$ overall & 0.380 & 0.386 & 0.592 & 0.545 & 0.296 & 0.502 \\
$\chi^{2}$ & $1,535.87$ & $2,271.90$ & $5,393.93$ & $2,926.12$ & $1,146.14$ & $2,253.46$ \\
Prob.> $\chi^{2}$ & 0.0000 & 0.0000 & 0.0000 & 0.0000 & 0.0000 & 0.000 \\
\hline \hline
\end{tabular}

Note: Summary regression results derived from (4).

Standard errors in parentheses.

Statistically significant at $* * * 1$ per cent, $* * 5$ per cent, $* 10$ per cent. 
Appendix 1: Definitions of Enterprise Characteristics

VARIABLE DEFINITION

1.Employment (Size) The total number of persons employed includes managerial, technical, clerical, and industrial employees, as well as apprentices.*

2. Skilled labour

3. Wages

4. Turnover

5. Labour turnover

6. Labour GVA

7. Capital intensity
Following the nomenclature of the CIE, skilled labour is defined as the sum of managerial, technical, and clerical employees. Skilled labour intensity is thus defined as managerial, technical, and clerical employees as a proportion of total employment.

Average wages are measured as the gross earnings of employees divided by the total number of employees.

Turnover comprises the net selling value of goods manufactured by the enterprise, of industrial services provided by the enterprise for others, of goods sold without further processing and the value of miscellaneous items of turnover (such as rents, licence fees, royalties, etc) (CSO, CIP, 1998a).

Labour turnover is defined as the average value of turnover produced by each employee.

Gross value added is defined as production value less intermediate consumption. Labour GVA is the average value of GVA produced by each employee.

The absence of a capital stock variable in the $C I E$ necessitates the use of 'Purchases of fuel and power' per employee as a proxy. ${ }^{* *}$

\footnotetext{
* The employment data of the Census does not represent full-time equivalents. Rather, individuals who are employed in the activities of the enterprise are included without accounting for the unit of employment (the number of hours worked) for which they are employed.

${ }^{* *}$ We recognise that this measure is subject to several imperfections; we are unable to distinguish the purchase of fuel from the purchase of power. Such a proxy measure does not take into account the efficiency of machinery used in the enterprise, or the level of capacity utilisation.
} 


\section{References}

Ahmad, J. and A. Kwan (1991). Causality between Exports and Economic Growth. Economic Letters 37: 243-248.

Aw, B. and A. Hwang (1995). Productivity and the Export Market: A Firm Level Analysis. Journal of Development Economics 47 (2): 313-332.

Baldwin, J. and W. Gu (2003). Export-market Participation and Productivity Performance in Canadian Manufacturing. Canadian Journal of Economics 36 (3).

Bartelsman, E. and M. Doms (2000). Understanding Productivity: Lessons from Longitudinal Micro-data Bases. Journal of Economic Literature 38 (3).

Bernard, A. and J. Jensen (1995). Exporters, Jobs, and Wages in US Manufacturing: 1976-1987. Brookings Papers on Economic Activity. Microeconomics 1995: 67-112.

Bernard, A. and J. Jensen (1999). Exceptional Exporter Performance: Cause, Effect, or Both? Journal of International Economics 47: 1-25.

Bernard A and J Wagner (1997). "Exports and Success in German Manufacturing", Weltwirtschaftliches Archiv, Vol. 133, pp. 134-157.

Central Statistics Office (1991a-1998a). Census of Industrial Production. Dublin: Government Publications.

Central Statistics Office (1991b-1998b). Economic Series. Dublin: Government Publications.

Central Statistics Office (1991c-1998c). Statistical Bulletin. Dublin: Government Publications. 
Clerides, S., S. Lach, and J. Tybout (1998). Is Learning-By-Exporting Important: MicroDynamic Evidence From Colombia, Mexico, and Morocco? Quarterly Journal of Economics 113: 903-948.

Eaton, J, S. Kortum, and F. Kramarz (2004). An Anatomy of International Trade: Evidence from French Firms, mimeo.

Girma, S., D. Greenaway, and R. Kneller (2002). Does Exporting Lead To Better Performance?: A Microeconomic Analysis of Matched Firms. Leverhulme Centre Research Paper 2002/09.

Girma, S., H. Gorg, and E. Strobl (2004). Exports, International Investment, and Plant Performance: Evidence from a Non-Parametric Test. Economics Letters (83): 317324.

Greenaway, D. and D. Sapsford (1994). What Does Liberalisation Do For Exports and Growth? Weltwirtschaftliches Archiv 130: 152-174.

Hansson, P. and N. Lundin (2004). Exports as an Indicator on or Promoter of Successful Swedish Manufacturing Firms in the 1990s. Review of World Economics 140 (3).

Helpman, E., M. Melitz, and S Yeaple (2004). Export versus FDI with Heterogenous Firms. American Economic Review (March): 300-316.

Meltiz, M. (2003). The Impact of Trade on Intra-Industry Reallocations and Aggregate Industry Productivity. Econometrica 71 (6).

Richardson, J. and K, Rindal (1995). Why Exports Really Matter! The Institute for International Economics and the Manufacturing Institute: Washington DC. 